\title{
STUDI KOMPARATIF TERHADAP PRINSIP DAKWAH AL-QUR'AN DAN INJIL SERTA WACANA MENJEMBATANI KONFLIK ISLAM DAN KRISTEN DI INDONESIA
}

\author{
Yuna Ulfah Maulina \\ UIN Sunan Kalijaga Yogyakarta, 55281, Indonesia \\ yunaulfah96@gmail.com
}

Article history:

Received : 2021-04-02

Revised : 2021-04-30

Accepted : 2021-06-20

Keywords:

Conflict,

Islam,

Christian,

Da'wah.
This paper attempted to examine the Islamic and Christian conflicts caused by da'wah or missions to spread religion by referring to the source of the da'wah call, namely the Qur'an and the Bible, and then compared them with the aim of finding common ground for the origin of the conflict. This research was a qualitative research (library research). The data were processed and analyzed by comparative descriptive method. The results showed that: first, Islam and Christianity were da'wah religions because it was evidenced from two holy book sources that both religions had verses calling to spread their religion. Second, after being investigated, the source of the conflict between Islam and Christianity was caused by certain elements who preached or conveyed religious but ignoring the prevailing ethics. Third, after tracing and reviewing and comparing the two sources of reference for the two religions, both Islam (Al-Qur'an) and Christianity (gospel) never justified da'wah carried out in an impolite way or cause a bloodshed. In contrast, the two religions often taught peace and love. Therefore, it was a need for re-reading and complete understanding of the da'wah verses both Islam and Christianity.

\section{ABSTRAK}

Tulisan ini ingin mengkaji konflik Islam dan Kristen yang disebabkan oleh dakwah atau misi penyebaran agama dengan merujuk pada sumber perintah dakwah tersebut yaitu Al-Qur'an dan Injil, serta kemudian membandingkan keduanya dengan tujuan dapat menemukan titik temu asal usul konflik tersebut. Penelitian ini merupakan penelitian kualitatif (library research) kemudian datadata diolah dan dianalisis dengan metode deskriptif komparatif. Hasil penelitian menunjukan bahwa: Pertama, Islam dan Kristen merupakan agama dakwah karena dibuktikan dari dua sumber kitab suci kedua agama ini sama-sama memiliki ayat yang memerintahkan untuk menyebarkan agamanya. Kedua, setelah diteliti ternyata, sumber konflik antara Islam dan Kristen ini karena terdapat oknumoknum tertentu yang berdakwah atau menyampaikan misi agama namun mengabaikan etika-etika yang berlaku. Ketiga, setelah menelusuri dan mengkaji serta membandingkan dalam dua sumber rujukan dua agama ini baik Islam (Al-Qur'an) maupun Kristen (Injil) tidak pernah membenarkan dakwah yang dilakukan dengan cara yang tidak santun apalagi sampai adanya pertumpahan darah, dan bahkan kedua agama ini adalah agama yang kerap kali mengajarkan kedamaian dan kasih sayang oleh sebab itu perlu adanya pembacaan ulang dan pemahaman yang utuh terhadap ayatayat dakwah baik Islam maupun Kristen. 


\section{Pendahuluan}

Islam dan Kristen adalah dua agama yang memiliki jumlah pemeluk paling banyak di dunia. Yang mana kedua agama tersebut sama-sama diakui bersumber dari Nabi Ibrahim (Syarifudin, 2014, hlm. 134). Islam dan Kristen memiliki sejarah konflik yang cukup panjang berawal dari saling mengklaim bahwa satu di antaranya merupakan penyimpangan dari agama dan ajaran yang sesungguhnya. Konflik IslamKristen di Eropa yang dikenal dengan perang Salib tahun 1096-1271 M yang merupakan konflik terparah dan terlama terjadi di dunia pada abad pertengahan. Berawal dari peristiwa tersebut sehingga kedepan terus bermunculan konflik-konflik yang tidak hanya seputar faktor berseberangan agama saja namun boleh jadi adanya faktor politik atau faktor lain yang justru lebih dominan namun tetap saja faktor utama penyebab terjadinya konflik yang berkepanjangan ini berawal karena faktor dasar yaitu agama. Hal ini karena masing-masing penganut agama mengklaim dirinya sebagai pemegang kebenaran dan seolah harus menumpas yang lain (Setiawan \& Soetapa, 2010, hlm. 5). Sejarah mencatat ketegangan antar umat beragama di Indonesia sering sekali terjadi terutama antara Islam dan Kristen (Zuhriyah, 2012, hlm. 220) meskipun Indonesia sendiri dikenal sebagai negara yang memiliki kebebasan beragama yang tinggi masih kerap sekali terjadi persengketaan antara umat Islam dan Kristen bahkan sampai bertumpah darah (Aritonang, 2004, hlm. 1). Akibat dari konflik yang sering terjadi ini membuat kecurigaan yang cukup besar antara dua agama besar ini hingga membuat terancam kerukunan umat beragama (Na"im, 1994, hlm. 67).

Islam dan Kristen memiliki beberapa kesamaan dalam ajarannya (Rahmi Ramdhiani Idris, 2017) salah satunya, keduanya termasuk agama dakwah (baca: istilah yang dipakai oleh orang Islam) atau agama misionaris (baca: istilah yang dipakai oleh Kristen), maksudnya suatu agama yang memiliki misi (Karen Armstrong, 2007, hlm. 72) menyiarkan kebenarannya dan membuat orang lain memeluknya (Wijayanti, 2016, hlm. 17). Orang Islam memiliki ideologi bahwa
Islam sebagai rahmat bagi seluruh alam, maka setiap Muslim memiliki tanggung jawab untuk mendakwahkan ajarannya menurut kemampuan masing-masing dan sesuai kesempatan yang dimiliki. Perintah untuk berdakwah tersebut sebagaimana terdapat pada Surah al-Nahl ayat 125 . Begitu pula orang Kristen baik itu katolik maupun protestan sama-sama memiliki ideologi menerima peranan dengan istilah yang termaktub dalam Injil "garam dunia": "Karena itu pergilah, jadikanlah seтиa bangsa murid-Ku dan baptislah mereka dalam nama Bapa dan Anak dan Roh Kudus". Laskar Kristus diperbolehkan menggunakan berbagai cara yang cerdik seperti yang disebutkan oleh Yesus dalam Matius 10:16 yang menjadi prinsip dasar penyemangat mereka "cerdik seperti ular dan tulus hati seperti burung merpati".

Oleh sebab itu problem akademik yang akan didiskusikan pada penelitian ini adalah mengingat kedua agama di atas yaitu Islam dan Kristen yang karena keduanya diperintahkan oleh kedua kitab suci mereka untuk menyeru dan menyebarkan ajarannya. Di situ kita bisa melihat bahwa tidak ada konotasi untuk memaksa seseorang atau melakukan cara yang licik untuk memasukkan seseorang kedalam suatu agama, namun fakta yang sering didapati dilapangan justru misi penyebaran agama sering menimbulkan konflik antara Islam-Kristen yang ujungujungnya menyebabkan terjadinya kekerasan, permusuhan, dan sebagainya seakan kitab sucilah yang menginginkan akan hal itu, padahal ketika merujuk kedalam kedua kitab suci agama ini tidak ditemui adanya pembolehan dan penghalalan sampai semacam ini dalam berdakwah. Padahal sikap semacam ini tidak dapat dibenarkan karena sebagai umat beragama semestinya saling bersikap toleransi dan memaknai secara teologis makna atas kehadiran agama lain. Oleh sebab itu ada tiga pertanyaan yang akan dijawab dan didiskusikan dalam penelitian ini dengan berharap nantinya dapat menjembatani konflik akibat misi penyebaran agama antara Islam dan Kristen. Pertama, bagaimana perintah dakwah dalam Al-Qur'an dan Injil? Kedua, bagaimana prinsip dakwah dalam Al-Qur'an dan Injil?, Ketiga, bagaimana 
menjembatani konflik akibat misi penyebaran agama antara Islam-Kristen?

Asumsi awal yang dibangun sebagai pijakan dalam tulisan ini adalah bahwasanya, pertama, konflik yang sering terjadi antara Islam dan Kristen di Indonesia disebabkan oleh salah satunya karena adanya kecurigaan antara kedua belah pihak karena dianggap saling merebut pemeluknya yang disebabkan oleh kegiatan dakwah yang tidak mengedepankan etika dan peranturan yang telah disepakati. Kedua, anjuran dan perintah untuk berdakwah memang terdapat dalam kedua kitab suci baik Kristen maupun Islam, namun dalam kedua kitab suci tersebut, tidak ditemui adanya unsur pemaksaan maupun licik dalam perintah berdakwah, justru harus mengedapankan etika yang santun. Ketiga, terjadinya konflik antar umat Islam dan Kristen terkait persoalan dakwah agaknya disebabkan kurangnya pemahaman mengenai pembacaan pada kitab suci terkait ayat-ayat perintah dakwah tersebut.

\section{Tinjauan Pustaka}

Dalam rangka untuk meningkatkan peran agama dalam ruang publik dewasa ini telah mendorong para pengamat dan akademisi untuk memahami lebih jauh tentang relasi antar agama (Latief, t.t., hlm. 174). Studi yang ada telah menunjukkan bahwa terjadinya konflik antara Islam dan Kristen yang berkepanjangan disebabkan karena adanya kecurigaan besar antara dua kelompok agama ini. Salah satu penyebab dari konflik ini karena misi Islamisasi dan Kristenisasi yang tidak memenuhi etika dan peraturan yang telah ditetapkan oleh negara terkait kesepakatan dakwah. Pembicaraan mengenai dakwah sesungguhnya sudah banyak menjadi pembahasan dalam literature para pakar dengan berbagai sudut pandang. Umumnya terdapat tiga pembicaraan yang membahas tentang dakwah, pertama pembahasan tentang dakwah sebagai alternative penyebaran agama (Banawiratma, 2006), kedua dakwah sebagai media komunikasi (Arbi, 2003), dan ketiga, dakwah sebagai sarana sosialisasi masyarakat (Librianti, 2019).

\section{Dakwah Sebagai \\ Menyebarkan Agama}

Pada mulanya, ketika mendengar kata dakwah tentu yang terbayang pertama kali adalah sebagai sebuah aktivitas yang bertujuan untuk mengkonversikan atau memindahkan seseorang dari satu sudut pandang ke sudut pandang lainnya. Dalam hal ini kegiatan dakwah sebagai sebuah upaya untuk memindahkan seseorang dari suatu agama ke agama lain, atau suatu aliran dalam agama ke aliran lainnya (Yahya, 2016, hlm. 81). Peran dakwah di sini memang terlihat cukup jelas sebagai sebuah cara untuk meningkatkan jumlah pemeluk dalam suatu agama, oleh sebab itu ia membutuhkan peran dari seorang pendakwah yang bertugas untuk menyampaikan ajaran agamanya, atau sebagai pengantara. Namun sebetulnya hakikat dakwah bukan hanya itu, dalam arti bukan hanya sekedar mengajak manusia untuk menerima seruan sang dai, bukan pula kepintaran seseorang berorasi di atas mimbar atau kemampuannya menuangkan ide dalam tulisan. Akan tetapi lebih dari itu, dakwah merupakan hubungan seseorang secara horizontal dengan sesama yang bersifat saling mempengaruhi (Ulum, Haramain, Nurkidam, \& Taufik, 2017, hlm. 125)

\section{Dakwah Sebagai Media Komunikasi}

Peran dakwah sebagai media komunikasi (Tahir \& Cangara, 2014, hlm. 187) dapat ditinjau dari dua dua sisi tergantung si penerima dakwah itu sendiri. Pertama, apabila dakwah ditujukan kepada pemeluk agama lain maka dakwah di sini dipandang sebagai Ilmu dakwah dalam konstruksi ilmiah yang memiliki peran sebagai media untuk dapat menerima sekaligus terbuka terhadap kebenaran ilmu lain (Arbi, 2003). Peran ini terlihat sangat elegan, karena seiring berkembangnya zaman, serta di tengah- tengah isu pluralisme keagamaan, peran dakwah sebagai media komunikasi dan verivikasi ilmu sangatlah dibutuhkan sehingga dapat membuka dialog antar agama serta dapat memperluas wawasan. Kedua, apabila dakwah dituju kepada sesama pemeluk agama, maka di sini peran komunikasi ditujukan kepada tokoh pendakwah, bagaimana ia dapat berkomunikasi dengan baik serta efektif dengan pendengar, 
supaya materi dakwah yang disampaikan masuk ke dalam pikiran penerima dakwah (Markarma, 2014), oleh sebab itu pendakwah harus mempelajari teknikteknik berkomunikasi yang nantinya dapat diaplikasikan dengan baik. Media yang digunakan dalam berdakwah pun sangat beragam seperti radio, televisi, media cetak (Tajuddin, 2015, hlm. 372) bahkan media sosial (Wibowo, 2019, hlm. 341) dan juga tempat-tempat khusus yang disediakan untuk bedakwah secara langsung.

\section{Dakwah Sebagai Sarana Sosialisasi Masyarakat}

Salah satu misi dari dakwah yang tidak kalah penting dan bahkan diyakini sebagai fungsi dakwah yang seharusnya adalah sebuah realitas sosial (Abdul Basit, 2013) yang dijadikan sebagai sarana untuk memnsosialisasikan masyarakat atau pemberdayaan masyarakat (Masrial, 2018, hlm. 71) untuk meningkatkan kualitas keimanan dan kesadaran mereka dalam beragama. Ada banyak upaya yang dapat diwujudkan dakwah agar perannya semakin terasa bagi masyarakat, contohnya dalam upaya pengembangan masyarakat misalnya memberi masyarakat materi dakwah yang bersifat sosiologis (Basit, 2013, hlm. 87), karena semakin ke zaman modern masyarakat memiliki semakin banyak persoalan yang komplek, oleh karena itu dakwah diharapkan mampu menjawab berbagai problematika umat baik itu problem ekonomi, kesehatan, pendidikan, budaya, sosial, dan religius. Dalam mengadapi problematika ini peran dakwah mengambil tempat debagai penyuluh dan penggagas yang memperkuat asas atau dasar yang sesuai dengan tuntutan kitab suci (Dianto, 2018, hlm. 117)

Tulisan yang sudah ada telah menjelaskan penggunaan dakwah sebagai media komunikasi yang dipakai untuk menyalurkan dan mendapatkan sebuah pengetahuan. Penggunaan dakwah sebagai media untuk menyebarkan agama masih dipertanyakan posisinya, dan mesti jelas kententuannya karena ia kerap kali menjadi sumber konflik antar umat beragama jika dilakukan dengan mengabaikan etika-etika yang berlaku. Sementara itu literature mengenai hal ini masih sangat minim dan terbilang luput dari kajian peneliti. Padalah dengan adanya kajian khusus mengenai prinsip dakwah dari berbagai agama kemungkinan besar dapat menjadi sarana untuk menengenahi konflik tersebut. Oleh sebab itu, kajian ini hadir untuk mencoba melengkapi kajian-kajian sebelumnya, karena ranah prinsip dakwah dari berbagai agama sangat luas, jadi penulis hanya akan mengambil dua perspektif agama saja yaitu Islam dan Kristen dan secara spesifik membandingkan prinsip dakwah dua agama tersebut berdasarkan sumber kitab suci keduanya dengan begitu hasil yang nantinya akan terlihat dapat diakui bersumber dari data-data yang otentik.

\section{Metodologi Penelitian}

Penelitian ini adalah penelitian kualitatif (Wahyuni, t.t., hlm. vii) (library research) dengan ilmu agama sebagai ruang lingkup penelitiannya. Data yang didapat kemudian disajikan secara deskriptif dengan menggunakan ilmu sosiologi agama. Sumber data dalam penelitian ini diklasifikasikan ke dalam dua golongan, yaitu data primer dan data sekunder. Data yang terkumpul kemudian dianalisis dengan menggunakan model analisis komparatif dan deduktif. Teknik analisis data penulis menggunakan content analysis dengan menganalisis data sesuai kandungan isinya. Dengan ini data-data yang penulis kumpulkan bersifat deskriptif dan data tekstual yang fenomenal, oleh karena itu dalam mengelola data-data tersebut penulis menggunakan analisis yaitu dengan cara komparatif dan deskriptif.

Selanjutnya, metode juga digunakan untuk menganilisis data dalam penelitian ini adalah induksi dan deduksi. Data-data yang telah diperoleh dalam penelitian ini akan dipelajari dan dikelompokkan sesuai dengan permasalahan. Data-data yang sudah dikelompokkan kemudian dipelajari dan diteliti lagi untuk diambil kesimpulan. Dari metode ini diharapkan dapat menyimpulkan konsep dakwah dalam AlQur'an dan Injil. 


\section{Hasil dan Diskusi}

\section{Perintah Dakwah dalam Al-Qur'an dan Bible}

"Dakwah" telah menjadi kosa kata bahasa Indonesia yang berarti mengajak umat mempelajari dan mengamalkan ajaran Islam. di samping itu, dakwah juga memiliki arti mengajak orang lain untuk berbuat kebaikan (Ali 1991, 135). Aplikasi dalam kehidupan masyarakat, kata dakwah identik dengan ceramah. Kalau dikatakan ustadz berdakwah, persepsi masyarakat adalah ceramah agama. Bukan menyalahkan pemahaman itu, namun sebenarnya kata dakwah mempunyai cakupan yang lebih luas lagi. Untuk mendudukan pemahaman makna kata dakwah, penulis merasa perlu menampilkan pengertian dakwah dalam tataran konsep keilmuan. Berikut ini, penulis menjelaskan pengertian dakwah secara etimologi dan terminologi.

Kata dakwah sendiri berasal dari bahasa Arab dan memiliki akar kata $و$ د : dal, 'ain, dan waw. Dari akar kata ini terangkai menjadi asal kata داع : دعى, da'a : دعى : yad'u, دعتح: da'watan, kata kerja داع : da'a, yang berarti memanggil, mengundang atau mengajak. Isim fa'ilnya (pelaku) adalah da'i yang berarti pendakwah. Di dalam kamus al-Munjid fi al-Lughoh wa alA'lam disebutkan makna da'i sebagai orang memangil (mengajak) manusia kepada agamanya atau mazhabnya untuk lebih jelasnya, berikut ini disajikan makna kata dakwah menurut analisis para ahli. Menurut Warson Munawir dalam Samsul Munir Amin, mengemukakan bahwa dakwah memiliki arti memanggil (to call), mengundang (to invite), mengajak (to summon), menyuruh (to propose), mendorong (to urge), dan memohon (to pray) (Dianto, 2018, hlm. 103).

Kustadi Suhandang menyebutkan dakwah Islamiyah berarti mengkomunikasikan ajaran Islam, dalam arti mengajak dan memanggil umat manusia agar menganut ajaran Islam memberi informasi mengenai amar makruf dan nahi mungkar, agar dapat tercapai kebahagiaan di dunia dan di akhirat serta terlaksananya ketentuan Allah. Faizah dan Muhsin Effendi menyimpulkan dakwah adalah kegiatan menyampaikan, mengajarkan serta mempraktekkan ajaran
Islam di dalam kehidupan sehari-hari. Pendapat mereka ini disandarkan pada pendapat Muhammad Abu al-Futuh dalam kitab al-madkhal ila 'ilm adda'wat yang mendefinisikan dakwah adalah menyampaikan dan mengajarkan ajaran Islam kepada seluruh manusia dan mempraktikkannya (thathbiq) dalam realitas kehidupan karena dakwah itu pada hakikatnya melalui tiga fase yakni penyampaian, pembentukan dan pembinaan. Oleh sebab itu dapat kita tarik kesimpulan bahwa definisi dakwah adalah sebuah kegiatan atau pekerjaan untuk menyebarkan kebenaran/kebaikan dalam hal ini "ajaran Islam" karena memang secara istilah dakwah sendiri berasar dari bahasa Arab dan kerap kali digunakan dalam Al-Qur'an dalam hal memerintahkan umat Islam untuk menyeru kebenaran agamanya.

Dalam Al-Qur'an terdapat 219 kali penyebutan kata dakwah dalam berbagai versi (Yahya, 2016, hlm. 88) terdapat banyak sekali ayat-ayat yang memberi perintah untuk berdakwah diantaranya firman Allah yang artinya: Ajaklah manusia ke jalan Tuhan-mu dengan cara yang bijaksana, pengajaran yang baik dan berdialoglah dengan mereka dengan caracara yang lebih baik (QS,al-Nahl:125) Kamu adalah ummat terbaik yang ditampilkan Allah di tengah-tengah manusia, menyuruh kepada yang ma'ruf dan mencegah perbuatan munkar (QS, Ali Imran:104) Hai orang-orang yang berselimut, Bangunlah, lalu berikan peringatan. Tuhan-mu Agungkanlah. Pakaian-mu sucikanlah. Perbuatan dosa tinggalkanlah (QS, al-Muddatsir:1-4) dan masih banyak terdapat pada ayat-ayat yang lain. Maka dari itu dapat dikatakan bahwa Islam adalah agama dakwah, bahkan semenjak pertama sekali Al-Qur'an turun Islam telah diproklamirkan Allah sebagai agama dakwah bahkan wahyu pertama sekali sudah memerintakan untuk membaca, yang mana membaca di sini bermakna mengenal dan mendekatkan diri kepada penciptanya (Zain, 2019, hlm. 47), dalam Islam, kewenangan untuk berdakwah itu bukan hanya diperintahkan untuk ulama atau tokoh ulama saja, namun perintahnya ditujukan kepada seluruh umat 
mulim(Prof. Dr. Moh. Ali Aziz, M.Ag, 2019).

Sama halnya dengan Islam, agama Kristen juga merupakan agama yang mempunyai misi untuk menyebarkan agamanya, namun ada perbedaan mengenai istilah yang dipakai oleh pemeluk Kristen, jika istilah yang dipakai oleh agama Islam adalah dakwah, maka istilah yang digunakan oleh agama Kristen dikenal dengan beberapa istilah seperti penginjilan, evengelisasi (Siahaan, 2017, hlm. 43), yang semuanya mengarah ke satu tujuan yaitu sebuah misi berbagi iman. Kata misi berasal dari bahasa Latin "missio" yang berarti pengutusan. Orang yang diutus disebut utusan atau rasul (bahasa Yunani "apostolos"). Yesus diutus oleh Allah, maka bisa disebut Rasul Allah. Para murid Yesus diutus oleh Yesus, mereka disebut Rasul-rasul Yesus Jemaat kristen sekarang juga mempunyai tugas pengutusan dari Allah melalui Yesus Kristus. Biasanya dipakai teks Matius 28: 18-20, yang oleh jemaat sering disebut "amanat agung". Dalam Injil Matius itu kita baca: "Kepada-Ku telah diberikan segala kuasa di surga dan di bumi. Karena itu pergilah, jadikanlah semua bangsa murid-Ku dan baptislah mereka dalam nama Bapa dan Anak dan Roh Kudus, dan ajarlah mereka melakukan segala sesuatu yang telah Kuperintahkan kepadamu. Dan ketahuilah, Aku menyertai kamu senantiasa sampai kepada akhir zaman".

Di situ kita menemukan tiga penggal pesan pengutusan (pergilah), yakni (a) memuridkan, (b) membaptis dalam nama Bapa, Anak dan Roh Kudus, dan (c) mengajari untuk melakukan segala sesuatu yang telah diperintahkan oleh Yesus. Ketiganya merupakan kesatuan dari tugas pengutusan yang diampaikan oleh Yesus. Kemudian satu janji: penyertaan Yesus sampai pada akhir zaman (Banawiratma, 2006, hlm. 6) Perintah yang sama juga terdapat dalam kitab Markus 16:15 "Lalu Ia berkata kepada mereka: "Pergilah ke seluruh dunia, beritakanlah Injil kepada segala makhluk". Beberapa penggalan ayat yang terdapat dalam Injil tersebut menunjukkan memang dalam agama Kristen juga ada perintah untuk menyebarkan ajaran agamanya.

\section{Persamaan dan Perbedaan Prinsip Dakwah dalam Al-Qur'an dan Bible}

Setelah mengetahui ayat-ayat perintah untuk menyebarkan agama dalam Al-Qura'an dan Bible, selanjutnya penting untuk mengkaji bagaimana sebetulnya konsep dakwah yang diperintahkan oleh masing-masing kitab suci baik Al-Qur'an maupun Injil sehingga nantinya adanya titik temu antara apa yang sebetulnya konsep yang terdapat dalam kitab suci dengan fakta yang ditemukan di lapangan apakah adanya keselarasan antara keduanya. Dimulai dengan konsep dakwah dalam Al-Qur'an. Al-Qur'an menyebutkan ayat-ayat dakwah dalam berbagai dimensi, di antaranya adalah dakwah sebagai tugas utama rasul, dakwah sebagai kewajiban, dakwah sebagai ibadah, materi dakwah, media dakwah, dan metode dakwah. Akan tetapi perlu dikhususkan dalam penelitian ini dakwah yang dimaksud adalah dakwah sebagai tanggung jawab pemeluk agama untuk menyebarkan agamanya dan mengajak orang lain untuk memeluk agamanya yang berlandaskan pada perintah kitab suci. Dalam hal ini penulis mengkhususkan lagi pada kitab suci AlQur'an dan Injil.

Prinsip penyebaran agama yang pertama sekali dipegang dalam Al-Qur'an adalah tugas dakwah adalah tugas umat secara keseluruhan, bukan monopoli golongan yang disebut ulama' atau cendekiawan. Dalam berdakwah, pelaku dakwah dituntut melakukan aktivitas dakwahnya secara santun, beradab dan menjunjung tinggi martabat manusia sebagai makhluq yang dimuliakan Allah. Al Qur'an memberikan landasan agar dakwah dilakukan secara hikmah sebagaimana tercantum dalam surat An Nahl ayat 125.

Dakwah tampil sebagai aktivitas yang membebaskan, meneguhan spiritual, dan menjadi penawar kegundahan batin manusia. Pertama, dakwah adalah menyampaikan. Tugas seorang juru dakwah adalah menyampaikan QS. Yasin (36): 17 dan memahami bahwa dakwah sangat erat hubungannya dengan hidayah. Kedua, dakwah bukan memaksa dan menguasai. Islam melarang memaksa mereka untuk memasuku agama Islam. Ayat Al-Qur'an yang melarang paksaan 
dalam menganut agama itu adalah turun sebelum Surat al-Taubat, di mana disyari'atkan memungut pajak (jizyah). Maka paksaan dalam menganut agama itu adalah terlarang secara mutlak. Begitu juga yang terdapat dalam Surah al-Baqarah ayat 256 yang berbunyi : "Tidak ada paksaan untuk memasuki agama Islam". menurut al-Sya'rawi ayat ini tidak berarti "tidak ada paksaan untuk melaksanakan sebagian ajaran islam", akan tetapi artinya adalah "tidak ada paksaan bagi siapapun untuk memasuki agama Islam, oleh sebab itu sebagai umat Islam kita tidak diperintahkan untuk memaksa orang lain untuk meyakini Allah, namun kita sebagai umat Islam fokus kepada diri sendiri untuk melaksanakan ajaran Islam (Anda Bertanya Islam Menjawab, 2005, hlm. 310). Ketiga, dakwah bukan mencela agama lain. Kegiatan dakwah atau misi tidak boleh dipenuhi dengan sindiran, sarkasme, cacian dan makian atas umat lain agama atau agama orang lain itu sendir dan tidak menyerupai penyebaran kebencian yang mengumbar umpatan dan olok-olok atas pihak luar. Keempat, berdakwah dengan visi dan misi dan yang jelas. Dakwah mempersuasi manusia kepada al-khayr, mewujudkan al-Ma'ruf, dan mencegaah kemungkaran agar tercipta masyarakat yang muflihun penuh dengna al-Falah dalam kehidupan dunia dan akhirat.

Begitu pula terkait prinsip penyebaran agama dalam Injil dapat kita melihat penjelasan dari 3 point yang terdapat dalam Matius 28: 18-20 sebagai berikut: Pertama, Tugas pengutusan untuk memuridkan (matheteusate) selayakanya dimengerti sejalan dengan cita-cita hidup keagamaan para murid Yesus. Memuridkan bukanlah sekedar usaha menambah jumlah anggota atau warga jemaat kristiani, yang biasanya terjadi melalui baptisan. Seandainya demikian maka "memuridkan" sama dengan mengusahakan terjadinya ritual baptisan. Menjadi murid Yesus bagi umat Kristiani berarti percaya kepada Anak Manusia Yesus sebagai Mesias, sebagai Juru selamat, sebagai Anak Allah yang menampilkan kehadiran Allah secara istimewa. Maka para murid bersama Yesus ikut serta memasuki gerakan Kerajaan
Allah, yakni kuasa dan pemerintahan Allah yang penuh bela rasa dan menyelamatkan. Sekarang ini, Yesus dijumpai pada wakilwakil-Nya didunia ini, yaitu saudarasaudari Yesus yang paling hina, dan setia kawan terhadap wakil-wakil Yesus itu. Memuridkan berarti mengantar orang untuk hidup menempuh jalan Yesus.

Kedua, Membaptis dalam nama (baptizontes eis to onoma) Bapa, Anak dan Roh Kudus berarti membaptis demi ibadah dan ketaatan serta pelayanan kepada Bapa, menempuh jalan Anak dalam daya kekuatan Roh Kudus. Baptisan merupakan inisiasi, orang yang dibaptis dimasukkan dalam jemaat para murid Yesus, yang mengikuti Yesus untuk menyerahkan diri kepada cinta kasih dan kehendak Allah saja. Penyerahan semacam itu hanya mungkin oleh karena Roh yang berkarya dan mengantar ke jalan Anak menuju Bapa. Baptisan merupakan tanda (sacramentum) kemuridan. Tanpa itu baptisan menjadi selembar kertas yang bisa dipakai untuk apa saja, termasuk yang berlawanan dengan Injil Yesus Kristus. Dengan meminjam penjelasan Rasul Paulus baptisan merupakan kesatuan dengan kematian Kristus dengan harapan akan hidup yang baru (Rom 6: 3-4). Memasuki baptisan dengan demikian berarti memasuki jalan, ikut serta dalam gerakan yanga mengantar Yesus ke kematian salib, yaitu gerakan Kerajaan Allah, daya kuasa dan pemerintahan Allah yang bekerja di tengah-tengah dunia sekarang ini. Ritual baptisan yang terlepas dari gerakan Yesus itu merupakan ritual yang tidak sesuai dengan hidup keagamaan menurut Injil. "Bukan setiap orang yang berseru kepada-Ku: Tuhan, Tuhan! akan masuk ke dalam Kerajaan Surga, melainkan dia yang melakukan kehendak Bapa-Ku yang di sorga" (Mat 7:21). "Setiap pohon yang baik menghasilkan buah yang baik, sedang pohon yang tidak baik menghasilkan buah yang tidak baik" (Mat 7:17). Baptisan yang hanya merupakan peristiwa seruan "Tuhan, Tuhan!" tanpa melakukan kehendak Bapa (sesuai dengan yang diperintahkan oleh Yesus) tidak memasukkan orang ke dalam Kerajaan Surga.

Ketiga, dari pesan "amanat agung" adalah tugas pengutusan untuk mengajar 
agar melakukan segala sesuatu (didaskontes terein panta) yang telah diperintahkan oleh Yesus. "Terein panta" berarti "memegang teguh, setia pada semua" yang telah diperintahkan dengan menjalankannya. Jadi bukan hanya kesetiaan dalam kata-kata, melainkan kesetiaan dalam tindakan nyata hidup sehari-hari. Inilah wujud kehidupan menjadi murid Yesus. Tanpa ini tanda yang diungkapkan dengan baptisan menjadi tanda yang tidak sesuai dengan apa yang mau ditandakan, yakni menjalani hidup sebagai murid Yesus. Apakah yang diperintahkan oleh Yesus? disebut golden rule: "Segala sesuatu yang kamu kehendaki supaya orang lain berbuat kepadamu, perbuatlah demikain juga kepada mereka" (Mat 7:12). Lalu "dua hukum yang terutama": "Kasihilah Tuhan, Allahmu, dengan segenap hatimu dan dengan segenap jiwamu dan dengan segenap akal budimu. Itulah hukum yang terutama dan yang pertama. Dan hukum yang kedua, yang sama dengan itu, ialah: Kasihilah sesamamu manusia seperti dirimu sendiri" (Mat 22: 37-39). Kemudian dari khotbah terakhir Yesus: "Segala sesuatu yang kamu lakukan untuk salah seorang dari saudara-Ku yang paling hina ini, kamu telah melakukannya untuk Aku" (Mat 25:40), "segala sesuatu yang tidak kamu lakukan untuk salah seorang dari yang paling hina ini, kamu tidak melakukannya juga untuk Aku" (Mat 25:45). Kesediaan para murid untuk menerima penyertaan Kristus tampak dari sejauh mana murid-murid terbuka dan berbuat bagi wakil-wakil Kristus di dunia sekarang ini.

Semenjak terbitnya buku David J. Bosch, Transforming Mission (1991), penggunaan istilah Missio Dei (pengutusan dari Allah) sebagai paradigma baru mengenai misi menegaskan bahwa pemilik misi adalah Allah yang menghendaki keselamatan semua orang. Gereja bukanlah pemilik misi, melainkan yang mendapat misi, yang menerima tugas pengutusan. Bukan hanya para klerus saja, melainkan kaum awam juga mendapat tugas pengutusan. Kesaksian bersama mengenai anugerah dan tindakan Allah yang menyelamatkan terjadi dalam kesatuan dari pelbagai karunia yang berbeda. Lagi pula keselamatan tidak dimengerti secara one dimensional, entah di dunia lain nanti atau di dunia ini sekarang ini. Sekarang ini misi berada dalam perjalanan ziarah menuju dunia baru yang akan datang. Keselamatan dimengerti secara komprehensif. Kesaksian mengenai Injil Yesus Kristus merupakan kesatuan dengan gerakan untuk melawan ketidakadilan dan untuk menegakkan keadilan.

Berdasarkan pemahaman mengenai misi seperti di atas, jelaslah bahwa misi tidak sama dengan usaha menambah jumlah anggota Gereja, apalagi merebut orang beragama lain menjadi anggota Gereja. Orang Kristen yang dengan sepenuh hati peduli terhadap kaum miskin dan menderita, yang memperjuangkan keadilan dan kemaslahatan bagi semua, tanpa menambah jumlah anggota orang Kristen satupun, adalah misionaris yang tulen. Yang terpenting dari perintah Injil bagi umat Kristiani bukanlah dari segi kuantitas namun kualitas iman.

Menjembatani Konflik Akibat Misi Penyebaran Agama Islam-Kristen

Sudah semestinya setiap pemeluk agama menginginkan agar agama yang dipeluknya memiliki banyak pengikutnya. Begitu juga agama Islam dan Kristen yang memang keduanya mengklaim agama mereka adalah agama dakwah yang mana dalam ajaran kedua agama ini memiliki perintah langsung dari kitab suci untuk menyebarkan ajaran agama mereka dan atas perintah itu tentu dijanjikan dengan pahala karena telah melakukan sebuah kebaikan.

Dalam lintas sejarah kerukunan umat beragama di Indonesia misalnya, pernah terjadinya kesepakan antara para pembesar agama pada waktu itu berupa pembatasan dakwah, bahwa dakwah untuk mengajak memeluk agama itu hanya boleh ditujukan bagi orang-orang yang belum beragama saja. Kesepakatan ini dibuat karena oleh para pembesar agama telah menyadari bagaimana konsekuensi yang akan terjadi nantinya jika kesepakatan ini tidak dibuat atau dilanggar karena di sini cikal bakan konflik awal akan muncul oleh karena itu mayoritas pembesar agama pada saat itu menyetujui akan kesepakatan ini kecuali Kristen (Yahya, 2016, hlm. 83), kendatipun begitu dalam pemuka agama 
Kristen terjadi pro kontra namun banyak juga yang menyetujui kesepakatan ini. Karena sejatinya yang dibutuhkan dalam keberagamaan di samping kuantivitasnya juga kualitas untuk menciptakan umat beragama yang tinggi ilmu, iman, dan pengabdian.

Namun nyatanya kesepakatan hanyalah kesepakatan, kenyataan di lapangan justru berbeda. Fakta menunjukkan berdakwah atau menyebarkan misi berbagi iman masih tetap saja tidak mengindahkan etika yang berlaku. Bahkan ada yang dengan rapi memprogramkan sesuatu yang endingnya untuk sebuah misi atau dakwah. Seperti kegiatan yang dilakukan oleh Vernon Brewer dari organisasi World Help pada saat tsunami Aceh dengan melakukan upaya kristenisasi pada 300 anak yatim Aceh, hal ini bahkan dikritisi langsung oleh salah satu guru besar Universitas Kristen melalui tulisannya (Banawiratma, 2006, hlm. 6). Kegiatan misi berbagi iman semacam ini tentu bertentangan dengan ajaran Kristen sesungguhnya yang otomatis bertentangan dengan Injil. Karena penambahan jemaat dengan cara yang seperti ini bukanlah buah dari berbagai imana melainkan ini merupak kegiatan manipulasi yang bertentangan dengan keluhuran martabat dan hak asasi manusia.

Sama hanya dengan kekhawatiran umat Islam atas Kristenisasi, umat Kristen juga memiliki ketakutan dengan upaya Islamisasi di ruang umum. Kekhawatiran itu tentu dengan alasan di Indonesia mayoritas penduduk muslim sehingga kebebasan mengekspresikan agama Islam lebih terlihat. Sebagai minoritas pemeluk Kristen merasa takut hak-hak nya akan dirampas seiring upaya Islamisasi membuat pemeluknya akan semakin berkurang. Kecurigaan semacam ini memang menimbulkan ketegangan dan konflik antara Islam dan Kristen sehingga pada akhirnya meruntuhkan keharmonisan hubungan antar umat beragama. Umat Islam menganggap umat Kristen tidak terpuji dalam melakukan misi penyebaran agamanya, serta umat Kristen menganggap umat Islam tidak toleran dan bersikap egois (Khotijah, 2008, hlm. 1)

Untuk menjembatani ketegangan dan konflik kedua agama ini (baca: Islam dan
Kristen) perlu untuk melakukan pembacaan ulang bagaimana sebetulnya perintah kitab suci baik Al-Qur'an maupun Injil untuk kemudian diimplementasikan sesuai dengan praktek dan prinsip dakwah yang dianjurkan kedua kitab suci tersebut. mengingat sama halnya terjadi pemelesetan terhadap makna jihad menjadi terorisme dan makna "sebar garam' menjadi misionaris dengan mengabaikan etika penyebaran agama. Bahkan jika kita merumuskan ulang apa yang dikatakan AlQur'an dan injil dalam ayat-ayat dakwah sungguh kita tidak akan menjumpai penyebaran agama secara radikal dan tidak terpuji.

Di samping itu perlu disadari pula, kedua agama ini senantiasa mengedepankan kedamaian dan kasih sayang. Yang justru kebalikan dari munculnya konflik dan persengketaan seperti yang marak terjadi dewasa ini. Ajaraan-ajaran tentang kasih sayang ini tentu sudah merangkap serta terkait peraturan dan etika dari misi dakwah agama tersebut yang pada prinsipnya akan menghindari penyebab dari rusaknya kedamaian itu sendiri. Oleh karena itu pembacaan ulang terhadap kitab suci dalam ranah dakwah sangat perlu dilakukan supaya misi tersebut berjalan sebagaimana seharusnya.

\section{Diskusi}

Al-Qur'an telah menegaskan telah menjadi tanggung jawab bagi setiap umat Islam untuk menyebarkan agamanya (baca: dakwah) untuk seluruh makhluk agar seluruh umat manusia menjumpai kebenaran. Namun Al-Qur'an menegaskan pula bahwa tidak ada paksaan dalam beragama, dalam arti untuk masuk kedalam agama Islam semsetinya tidak ada interfensi dari orang lain murni karena penerimaannya sendiri sehingga tidak ada satupun manusia yang berhak memaksa orang lain untuk memeluk agama Islam. kata kunci yang dapat diambil dari pernyataan Al-Qur'an tersebut adalah tugas berdakwah itu wajib dan tanggung jawabnya dititipkan bagi setiap umat Islam namun persoalan seseorang mau masuk Islam itu terserah orang yang didakwahi itu, sementara orang yang berdakwah tidak 
dibenarkan melakukan pemaksaan untuk memasukkan orang lain kepada agama Islam. Begitu pula prinsip yang didapati dalam ayat-ayat berbagi iman dalam Kristen yang dijuluki dengan istilah pemegang "amanat agung" juga mempunyai prinsip tidak memaksakan seseorang untuk memeluk agama Kristen bahkan yang diutamakan adalah kualitas iman bukan kuantitas dari segi menambah pemeluk.

Berdasarkan temuan dari kedua kitab suci yaitu Al-Qur'an dan Injil yang membahas mengenai prinsip-prinsip dakwah tersebut ternyata dapat disimpulkan keduanya tidak berorientasi adanya indikasi pemaksaan dan juga tidak boleh memasukkan orang lain kepada dua agama tersebut dengan cara yang tidak terpuji atau mengabaikan nilai-nilaki hak asasi manusia sebagaimana yang banyak dipraktekan oleh beberapa oknum tokoh agama saat ini. Oleh sebab itu sungguh tidak dapat dibenarkan kegiatan-kegitatan islamisasi atau kristenisasi semacam ini berasal dari perintah Tuhan. Karena kedua kitab suci ini baik Al-Qur'an maupun Injil menjelaskan etika-etika yang terpuji dalam berdakwah sehingga sengkiranya dapat diterapkan oleh penganutnya pula sesuai dengan yang diajarkan oleh kitab suci masing-masing.

Penelitian-penelitian seperti ini sebetulnya masing luput dari kajian peneliti terutama di Indonesia. Karena penelitian-penelitian sebelumnya terkait dakwah antara Islam dan Kristen sering mendiskreditkan agama yang tidak diantut oleh peneliti tersebut. kebanyakan didapati penelitian semacam ini hanya memperlihatkan perbedaan keduanya tanpa menjelaskan bagaimana seharusnya bertindak. Dan juga penelitian-penelitian sebelumnya sejauh pembacaan penulis hanya menjelaskan bagaimana dakwah versi agama Islam dan Kristen, oleh sebab itu, tulisan ini hadir untuk melengkapi kekurangan literature-literature terdahulu. Penelitian ini secara fokus mengkaji perbandingan pada kedua kitab suci agama ini untuk melihat secara langsung bagaimana sebetulnya prinsip dakwah dua agama ini langsung dari sumber utama rujukan keduanya. Untuk melihat relevansi dengan fakta sosial yang ditemukan di masyarakat apakah sesuai dengan yang dikatakan dalam kitab suci keduanya.

Dengan adanya penelitian ini diharapkan dapat menjadi pencerahan dalam membaca kitab suci tentang prinsip dakwah Islam dan Krinsten dalam AlQur'an dan Injil sehingga dengan ini dapat menghapus kecurigaan dan konflik dua agama ini dan menyadarkan bahwa tidak ada agama yang mengajarkan permusuhan apalagi ajaran yang dapat merampas hak asasi manusia. Oleh sebab itu apabila didapati adanya penyimpangan dalam upaya Islamisasi maupun Kristenisasi yang tidak sesuai dengan ajaran dari kitab sucinya dapat dipastikan hal tersebut karena adanya motiv tersendiri dibelakangnya.

\section{Kesimpulan}

Berdasarkan hasil dari penelitian di atas dapat ditarik beberapa kesimpulan sebagai solusi dari masalah konflik IslamKristen di Indonesia yang diakibatkan oleh isu dakwah. Pertama, perlu diakui memang benar dua agama ini yakni Islam dan Kristen merupakan agama dakwah karena dibuktikan dari dua sumber kitab suci kedua agama ini sama-sama memiliki ayat yang memerintahkan untuk menyebarkan agamanya, meskipun terdapat perbedaan antara Islam dan Kristen mengenai posisi siapa yang berperan dalam kegiatan penyebaran ini, jika Islam peran ini diberikan kepada setiap pemeluk Islam tanpa terkecuali, sementara Kristen hanya kepada orang-orang tertentu yang memiliki julukan pemegang "amanat agung". Kedua, perlu diperhatikan lagi bahwa sumber konflik antara Islam dan Kristen (Armstrong, 2003, hlm. 15) ini karena terdapat oknum-oknum tertentu yang berdakwah atau menyampaikan misi agama namun mengabaikan etika-etika yang berlaku sebagaimana yang telah disepakati oleh para pemuka agama, bahwa dakwah itu hanya boleh ditujukan kepada orang-orang yang belum memeluk agama apapun. Ketiga, solusi dari masalah ini adalah dengan melakukan pembacaan ulang kepada kitab suci agama ini baik Islam (Al-Qur'an) maupun Kristen (Injil) karena setelah diteliti ternyata kedua kitab suci ini memiliki prinsip dakwah dengan 
tanpa paksaan, santun, serta harus menghormati umat agama lain. Inilah sebetulnya solusi yang sangat perlu dibaca ulang, sehingga jika memahami betul makna ayat-ayat dakwah dalam Al-Qur'an maupun Injil, sungguh sebetulnya konflik yang diakibatkan oleh dakwah atau misi penyebaran agama tidak mungkin terjadi, karena prinsip utama dari substansi dakwah dalam Al-Qur'an maupun Injil adalah kualitas iman bukan hanya kuantitas saja.

\section{Daftar Pustaka}

Abdul Basit, D. (2013). Filsafat Dakwah. Rajawali Pers. Diambil dari http://repository.iainpurwokerto.ac.id/33 63/

Anda Bertanya Islam Menjawab. (2005). Depok: Gema Insani.

Arbi, A. (2003). Dakwah dan Komunikasi. UIN Jakarta Press. Diambil dari http://repository.uinjkt.ac.id/dspace/hand le/123456789/41242

Aritonang, J. S. (2004). Sejarah perjumpaan Kristen dan Islam di Indonesia. BPK Gunung Mulia.

Armstrong, K. (2003). Perang suci: Dari perang salib hingga perang teluk. Penerbit Serambi.

Banawiratma, J. B. (2006). Misi Dan Dakwah Berbagi Iman Demi Kemaslahatan Umat Manusia. Gema Teologi, 30(2). Diambil dari http://journal-

theo.ukdw.ac.id/index.php/gema/article/ view/88

Basit, A. (2013). Dakwah Cerdas di Era Modern. Jurnal Komunikasi Islam, 3(1). https://doi.org/10.15642/jki.2013.3.1.\%p

Dianto, I. (2018). Peranan dakwah dalam proses pengembangan masyarakat Islam. HIKMAH: Jurnal Ilmu Dakwah dan Komunikasi Islam, 12(1), 98-118.
Karen Armstrong. (2007). Muhammad Prophet for Our Time. Bandung: Mizan Pustaka.

Khotijah. (2008). Konsep Dakwah Terhadap Orang-orang Non Muslim (yang Beragama Lain) menurut Jalaluddin Rakhmat dalam Buku "Islam dan Pluralisme." Dalam Skripsi. Semarang: IAIN Walisongo Semarang.

Latief, H. (t.t.). Agama Dan Pelayanan Sosial: Interpretasi Dan Aksi Filantropi Dalam Tradisi Muslim Dan Kristen Di Indonesia. (2), 16.

Librianti, E. O. I. (2019). Budaya tahlilan sebagai media Dakwah: Studi terhadap masyarakat Nahdliyin di Kelurahan Cipadung Kecamatan Cibiru Kota Bandung (Masters, UIN Sunan Gunung Djati Bandung). UIN Sunan Gunung Djati Bandung. Diambil dari http://digilib.uinsgd.ac.id/24404/

Markarma, A. (2014). Komunikasi Dakwah Efektif Dalam Perspektif Alquran. HUNAFA: Jurnal Studia Islamika, 11(1), 127-151.

https://doi.org/10.24239/jsi.v11i1.344.12 7-151

Masrial, M. (2018). Dakwah Dan Pemberdayaan Masyarakat. Turast : Jurnal Penelitian dan Pengabdian, 6(1), 67-78. https://doi.org/10.15548/turast.v6i1.689

Mukti Ali. (1991). Memahami Beberapa Aspek Ajaran Islam. Bandung: Mizan.

Na"im, K. (1994). Organisasi Islam Menghadapi Kristenisasi. Gema Insani.

Prof. Dr. Moh. Ali Aziz, M.Ag. (2019). Ilmu Dakwah: Edisi Revisi. Prenada Media.

$Q S$. (t.t.).

Rahmi Ramdhiani Idris, 12210495. (2017). Titik Temu Islam dan Kristen Perspektif AlQur'an (Studi Komparatif Kitab AlJâmi' li Ahkâm Al-Qur'ân Karya alQurthubi dan Kitab Al-Azhar Karya Buya Hamka). Diambil dari 
http://repository.iiq.ac.id//handle/123456 $789 / 670$

Setiawan, M. N. K., \& Soetapa, D. (2010). Meniti kalam kerukunan: Beberapa istilah kunci dalam Islam dan Kristen. BPK Gunung Mulia.

Siahaan, D. S. (2017). Ketika Aku dan Kamu Menjadi Kita: Dialog Misi Penginjilan Kristen dengan Dakwah Islam Menggunakan Pendekatan Teologi Interkultural dalam Konteks Indonesia. GEMA TEOLOGIKA: Jurnal Teologi Kontekstual dan Filsafat Keilahian, 2(1), 41-54.

https://doi.org/10.21460/gema.2017.21.2 80

Syarifudin, A. P. (2014). [resensi] Belajar Dari Hubungan Islam-Kristen: Upaya Menciptakan Masa Depan Harmonis. RELIGI JURNAL STUDI AGAMAAGAMA, 10(1), 134.

https://doi.org/10.14421/rejusta.2014.10 01-08

Tahir, Q., \& Cangara, H. (2014). Masjid Kampus Sebagai Media Komunikasi Aktivis Dakwah Dalam Pembentukan Karakter Mahasisw A. KAREBA : Jurnal Ilmu Komunikasi, 186-192. https://doi.org/10.31947/kjik.v3i3.588

Tajuddin, Y. (2015). Walisongo Dalam Strategi Komunikasi Dakwah. ADDIN, 8(2). https://doi.org/10.21043/addin.v8i2.602

Ulum, A. C., Haramain, M., Nurkidam, A., \& Taufik, M. (2017). Eksistensi Dakwah Dalam Merespon Pluralisme. KOMUNIDA : Media Komunikasi Dan Dakwah, 7(2), 124-138. https://doi.org/10.35905/komunida.v7i2. 475
Wahyuni, S. (t.t.). Fakultas Dakwah Institut Agama Islam Negeri Walisongo Semarang. 10.

Wibowo, A. (2019). Penggunaan Media Sosial Sebagai Trend Media Dakwah Pendidikan Islam Di Era Digital. JURNAL ISLAM NUSANTARA, 3(2), 339-356. https://doi.org/10.33852/jurnalin.v3i2.14 1

Wijayanti, T. Y. (2016). Konsep Kebebasan Beragama Dalam Islam Dan Kristen. Profetika: Jurnal Studi Islam, 17(01), 16. https://doi.org/10.23917/profetika.v17i0 1.2097

Yahya, Y. (2016). Dakwah Islamiyah Dan Proselytisme; Telaah Atas Etika Dakwah Dalam Kemajemukan. INJECT (Interdisciplinary Journal of Communication), 1(1), 81-98. https://doi.org/10.18326/inject.v1i1.8198

Zain, A. (2019). Dakwah Dalam Perspektif AlQur'an Dan Al-Hadits. At-Taujih : Bimbingan dan Konseling Islam, 2(1). https://doi.org/10.22373/taujih.v2i1.7209

Zuhriyah, L. F. (2012). Dakwah Inklusif Nurcholish Madjid. Jurnal Komunikasi Islam, 2(2). https://doi.org/10.15642/jki.2012.2.2.\%p 